\title{
TESTING FOR INDONESIAN AND VIET NAM PRICE TRANSMISSION IN THE UNITED STATES TUNA MARKETS
}

\author{
${ }^{* 1}$ Wiranthi, Puspi Eko \\ ${ }^{* 1}$ Department of Agribusiness, UIN Syarif Hidayatullah Jakarta, Jakarta - Indonesia \\ Note: * Indicates corresponding author
}

\begin{tabular}{|c|c|}
\hline ARTICLE DETAILS & \multirow{4}{*}{$\begin{array}{l}\text { ABSTRACT } \\
\text { This study aims to analyze Indonesia and Viet Nam price } \\
\text { transmission as the main exporters of frozen yellowfin tuna to the } \\
\text { United States (US) assuming that the market structure is oligopoly. } \\
\text { Using monthly time series data of Indonesia, Viet Nam and US } \\
\text { frozen yellowfin tuna prices with harmonized system code } \\
03034200 \text { from January } 2006 \text { to December } 2018 \text { and analyzed } \\
\text { through an Asymmetric Error Correction Model (AECM), this study } \\
\text { finds that both prices of Indonesia and Viet Nam are integrated to }\end{array}$} \\
\hline $\begin{array}{l}\text { Article History } \\
\text { Published Online: publisher use } \\
\text { only }\end{array}$ & \\
\hline $\begin{array}{l}\text { Keywords } \\
\text { Price transmission, The US frozen } \\
\text { yellowfin tuna imports, Indonesia, } \\
\text { Viet Nam, Price }\end{array}$ & \\
\hline “Corresponding Author & \\
\hline Email:puspiew@uinjkt.ac.id & $\begin{array}{l}\text { the US prices. Additionally, there are two-way causality } \\
\text { relationships between both exporting countries as well as Viet } \\
\text { Nam and the US. The short-term price transmission of Viet Nam } \\
\text { has an asymmetrical effect on Indonesian prices while on the long- } \\
\text { term, the price transmission among three countries occurs } \\
\text { symmetrically which indicates that a competitive international } \\
\text { market exists. Indonesia's policy in increasing its market share in } \\
\text { the US is not independent, but it is influenced by the price of Viet } \\
\text { Nam as its main competitor. The findings of this study are relevant } \\
\text { to fill the gap in the literature by providing a supporting evidence } \\
\text { regarding price transmission between two main exporters to the } \\
\text { US frozen yellowfin tuna market. }\end{array}$ \\
\hline
\end{tabular}

\section{INTRODUCTION}

Yellowfin tuna is the most imported tuna by the US today after Albacore (Statista, 2019). Indonesia is a major exporter of frozen yellowfin tuna to the US, yet since 2015, its position has been shifted by Viet Nam where the export trends continue to increase (Figure 1). In addition, the average price per ton of Viet Nam imported tuna is higher than Indonesia (Figure 2). Another issue is that yellowfin tuna has been overfished in several parts of Indonesia due to poor fisheries management (Masrizal \& Naufal, 2019). The US has shifted its market demand for more sustainable seafood products by set ecofriendly standards for imported tuna to maintain the qualities, prevent illegal catches, unreported and unregulated activities, improve tuna traceability, and help realize a fair and legal trade for fishermen (Ministry of Maritime Affairs and Fisheries, 2018; Yusuf, Arthatiani, \& Maharani, 2018). In addition, the US becomes Indonesia's main export destination market for frozen tuna fillets with export value in 2017 reaching 60 million dollars (Indonesian Pole \& Line and Handline Fisheries Association, 2019).

Faculty of Economics and Business, Universitas Brawijaya
Figure 1. The US imported volume from five main countries

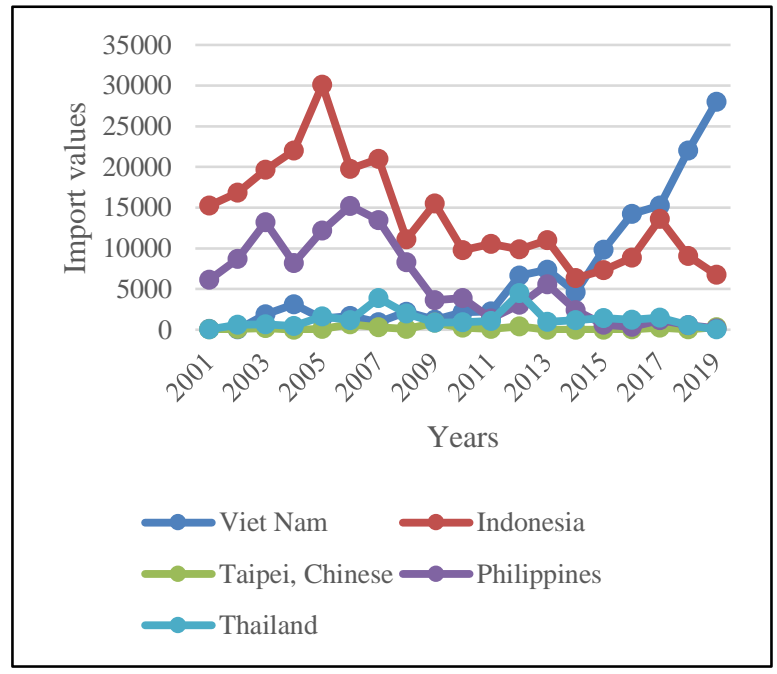

Source: ITC Trade Map, 2020

The pattern of the US frozen imported yellowfin tuna price movements from Indonesia and Viet Nam has remained stable over the past 
10 years (Figure 2). Both prices are above the average imported price in the US market. During 2010 to 2019, Indonesia average price was above Vietnam average price, yet since the third quartile of 2012, the opposite condition occurs. In addition, there are disparities in price adjustments between the two exporting countries due to increasing or decreasing prices. Asymmetrical price transmission occurs when there is a difference in price response between positive and negative price shocks. Several common factors are imperfect competition due to information lag, promotion, market concentration, market power which is characterized by the role of price leadership, and the existence of adjustment costs. Two interconnected markets, which are perfectly integrated and price changes from a market are transmitted symmetrically to another have become an important evidence of the Law of One Price (LOP) (Henderson \& Quant, 1980; Von Cramon \& Taubadel, 1997; Zachariasse \& Bunte, 2003).

\section{Figure 2. Movement of frozen yellowfin tuna prices in the US market from January 2010 to December 2019}

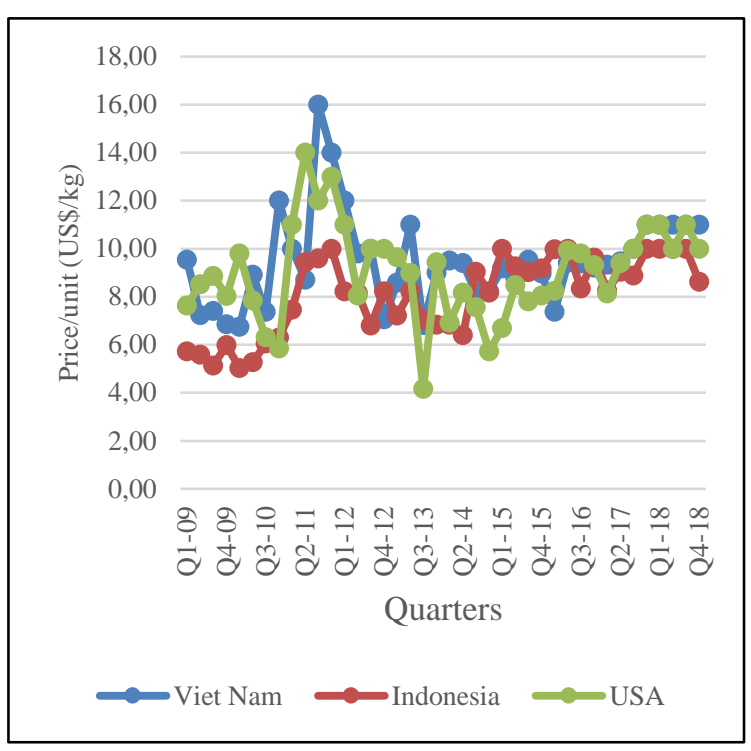

Source: ITC Trade Map, 2020

The prior literature on price transmission of tuna prices is limited. Previous studies presented market integration and transmission of tuna prices, including Jeon, Reid, \& Squires (2008) that tested the market integration of yellowfin tuna. The results indicated that the yellowfin tuna market was not integrated by price. Likewise, Matsui et al (2011) and Nakajima, Matsui, Sakai, \& Yagi (2011) stated that the price transmission of Bluefin tuna is asymmetrical. However, several other studies

Faculty of Economics and Business, Universitas Brawijaya indicated that the yellowfin tuna market is well integrated, including Jiménez-Toribio, Guillotreau, \& Mongruel (2010), Pan, Sun, \& Squires (2010) and Huang \& Leung (2011). In this study, we analyze Indonesia and Viet Nam price transmission as the main exporters of frozen yellowfin tuna to the US assuming that the market structure is oligopoly. This assumption underlies the argument that Indonesia prices are influenced by the prices of Viet Nam as its main competitor. This research fills the gap in the literature by providing supporting evidence regarding price transmission between two competing markets in frozen yellowfin tuna. Asymmetric price transmission will be an indicator of market failure and net welfare loss for Indonesia. With the fact that the US is the main market for frozen tuna fillets, the results of this study will be an important note for Indonesia's policies. When the US imported prices are not fully transmitted to the Indonesian market in the long run, the market position can be easily replaced by Viet Nam. The rest of the studies are described as follows. In the next section, the theories that underlie this research are explained. The third section explains the methodological approach and econometric specifications used. The fourth section will display empirical results and discussions while the fifth section will conclude the results with some remarks.

\section{MARKET INTEGRATION, THE LAW OF ONE PRICE (LOP), AND ASYMMETRIC PRICE TRANSMISSION}

Market integration has become an important issue in the literature on seafood market behavior through price linkages (Jaffry et al, 2000; Nielsen, 2005). Markets are fully integrated when the price changes in one market are relatively constant with prices in others and both are substitute products. In this assumption, the LOP holds (Vinuya, 2007). A common way used to test market integration is by using a cointegration test as introduced by Engle \& Granger (1987). Cointegration provides stable long-term relationship results for variables that are not stationary or contain trends (Vinuya, 2007). If two markets are integrated in the shortterm, price increases in one market will be continued and fully reflected in the other market while price adjustments in the short-term will return to equilibrium levels in the long run when both are integrated in the long-term (Ravaillon, 1996). Some advantages of this setting, especially for developing countries, are helping to increase the livelihood of small-scale producers (Van Campenhout, 2007).

The issue of asymmetric price 


\section{TESTING FOR INDONESIAN AND VIET NAM PRICE TRANSMISSION IN THE UNITED STATES TUNA MARKETS}

transmission has received a great attention from economic theory. There is often a price gap between price theories and the practices in the market and it brings a significant impact on policies, especially in terms of international trade (Pelzman, 2000). Price transmission will guarantee horizontal and vertical market integration (Meyer \& von Cramon-Taubadel, 2004). According to Meyer \& von CramonTaubadel (2004), there are two types of asymmetric price transmission, which are based on the magnitude or speed. This price transmission can occur vertically from farm gate to retail prices or horizontally between two spatially separated markets. In addition, the transmission can occur both positively where faster reaction occurs to price increases and negatively when it happens otherwise. According to empirical evidences, the main causes of asymmetric price transmission are market power (Borenstein et al., 1997; Damania \& Yang, 1998), adjustment costs (Ball \& Mankiw, 1994; Buckle \& Carlson, 2000; Chavas \& Mehta, 2004), input substitution (Bettendorf \& Verboven, 2000), the nature of agricultural marketing systems, pricing costs at the retail level and methods for collecting and reporting price data (Kinnucan \& Forker, 1987). Empirical studies on most of agricultural products have proven that rising prices on farm prices are transmitted more quickly to retail than falling prices (Carman \& Sexton, 2005; Richards \& Patterson, 2003; Miller \& Hayenga, 2001; Dong, Brown, Waldron, \& Zhang , 2018) as well as the transmission of spatial prices, especially where price reductions on the international market are often transmitted to the domestic market faster compared to price increases (Mundlak \& Larson, 1992). This asymmetrical price transmission will create potential danger for developing countries that have many small-scale producers (Mosley \& Suleiman, 2007).

\section{METHODS}

This study relies on monthly time series of export prices of Indonesia, Viet Nam and the US frozen yellowfin tuna with harmonized system code 03034200 which are collected from the ITC Trade Map from January 2006 to December 2018 that was counted for 156 months. The AECM is used as suggested by Meyer \& von Cramon-Taubadel (2004) through the E-Views 10 statistical package. The following specifications are used:

$\Delta P X Y I_{t}=\alpha_{0}+\sum \beta_{1 i}^{-} \Delta P X Y I_{t-i}^{-}+\sum \beta_{2 i}^{-} \Delta P X Y V_{t}^{-}+$ $\sum \beta_{2 i}^{-} \Delta P X Y V_{t-i}^{-}+\pi_{1}^{-} E C T_{t-1}^{-}+\sum \beta_{4 i}^{+} \Delta P X Y I_{t-i}^{+}+$ $\sum \beta_{3 i}^{+} \Delta P X Y V_{t}^{+}+\sum \beta_{4 i}^{+} \Delta P X Y V_{t-i}^{+}+\pi_{2}^{+} E C T_{t-1}^{+}+\varepsilon_{t}$
$\Delta P X Y I_{t}=\alpha_{0}+\sum \beta_{1 i}^{-} \Delta P X Y I_{t-i}^{-}+\sum \beta_{2 i}^{-} \Delta P X Y U_{t}^{-}+$
$\sum \beta_{2 i}^{-} \Delta P X Y U_{t-i}^{-}+\pi_{1}^{-} E C T_{t-1}^{-}+\sum \beta_{4 i}^{+} \Delta P X Y I_{t-i}^{+}+$
$\sum \beta_{3 i}^{+} \Delta P X Y U_{t}^{+}+\sum \beta_{4 i}^{+} \Delta P X Y U_{t-i}^{+}+$
$\pi_{2}^{+} E C T_{t-1}^{+}+\varepsilon_{t}$

$\Delta P X Y V_{t}=\propto_{0}+\sum \beta_{1 i}^{-} \Delta P X Y V_{t-i}^{-}+$

$\sum \beta_{2 i}^{-} \Delta P X Y I_{t}^{-}+\sum \beta_{2 i}^{-} \Delta P X Y I_{t-i}^{-}+\pi_{1}^{-} E C T_{t-1}^{-}+$ $\sum \beta_{4 i}^{+} \Delta P X Y V_{t-i}^{+}+\sum \beta_{3 i}^{+} \Delta P X Y I_{t}^{+}+$

$\sum \beta_{4 i}^{+} \Delta P X Y I_{t-i}^{+}+\pi_{2}^{+} E C T_{t-1}^{+}+\varepsilon_{t}$

$\Delta P X Y V_{t}=\propto_{0}+\sum \beta_{1 i}^{-} \Delta P X Y V_{t-i}^{-}+$

$\sum \beta_{2 i}^{-} \Delta P X Y U_{t}^{-}+\sum \beta_{2 i}^{-} \Delta P X Y U_{t-i}^{-}+\pi_{1}^{-} E C T_{t-1}^{-}+$

$\sum \beta_{4 i}^{+} \Delta P X Y V_{t-i}^{+}+\sum \beta_{3 i}^{+} \Delta P X Y U_{t}^{+}+$

$\sum \beta_{4 i}^{+} \Delta P X Y U_{t-i}^{+}+\pi_{2}^{+} E C T_{t-1}^{+}+\varepsilon_{t}$

$\Delta P X Y U_{t}=\alpha_{0}+\sum \beta_{1 i}^{-} \Delta P X Y U_{t-i}^{-}+$

$\sum \beta_{2 i}^{-} \Delta P X Y I_{t}^{-}+\sum \beta_{2 i}^{-} \Delta P X Y I_{t-i}^{-}+\pi_{1}^{-} E C T_{t-1}^{-}+$

$\sum \beta_{4 i}^{+} \Delta P X Y U_{t-i}^{+}+\sum \beta_{3 i}^{+} \Delta P X Y I_{t}^{+}+$

$\sum \beta_{4 i}^{+} \Delta P X Y I_{t-i}^{+}+\pi_{2}^{+} E C T_{t-1}^{+}+\varepsilon_{t}$

$\Delta P X Y U_{t}=\propto_{0}+\sum \beta_{1 i}^{-} \Delta P X Y U_{t-i}^{-}+$

$\sum \beta_{2 i}^{-} \Delta P X Y V_{t}^{-}+\sum \beta_{2 i}^{-} \Delta P X Y V_{t-i}^{-}+\pi_{1}^{-} E C T_{t-1}^{-}+$

$\sum \beta_{4 i}^{+} \Delta P X Y U_{t-i}^{+}+\sum \beta_{3 i}^{+} \Delta P X Y V_{t}^{+}+$

$\sum \beta_{4 i}^{+} \Delta P X Y V_{t-i}^{+}+\pi_{2}^{+} E C T_{t-1}^{+}+\varepsilon_{t}$

Where:

PXYI $\quad=$ The export price of Indonesia frozen yellowfin tuna (US $\$ / \mathrm{kg}$ )

PXY $V_{t} \quad=$ The export price of Viet Nam frozen yellowfin tuna (US\$/kg)

$\mathrm{PXYU}_{t} \quad=$ The export price of the US frozen yellowfin tuna (US\$/kg)

$E C T_{t-1}^{-}, E C T_{t-1}^{+}=$The speed of price adjustments

$$
\begin{array}{ll}
\pi_{t}^{-}, \pi_{t}^{+} & =\text {Coefficients of ECTs } \\
\mathrm{k}, \mathrm{I} & =\text { Lag length } \\
\varepsilon_{i, j} & =\text { Error }
\end{array}
$$

The hypothesis that will be tested is whether there is an existence of price transmission between markets in the short and long term. The model in this study follows an empirical testing procedure, first by testing data stationarity through the Augmented DickeyFuller (ADF) unit root test. The purpose of this test is to determine whether the variable contains unit roots to avoid spurious regression (Songsiengchai, Sidique, Djama, \& AzmanSaini, 2018). Second, by testing the cointegration relationship between variables through the Johansen cointegration test (Johansen, 1988), evaluating the trace and maxeigen value test statistics (Turner, 2009), 
and testing whether the error produced is stationary through the ADF unit root residual test (Li, Wang, \& Liu, 2013). Third, by testing the causality relationship between variables through the Granger causality test (Lemmens, Croux, \& Dekimpe, 2008).

Fourth, by estimating AECM by using the first difference variable to produce an error correction term (ECT) which is interpreted as a deviation from equilibrium (Engle \& Granger, 1987). Price transmission in this study is differentiated into short-term and long-term price transmission. The short-run price transmission is evaluated from the coefficient value of the independent variable, while the long-term price transmission is evaluated from the ECT coefficient value. The ECT coefficients evidence the condition of the price deviation from its equilibrium price. The $\mathrm{ECT}^{+}$indicates a price deviation above the long-term equilibrium, while the ECT- indicates a price deviation below the long-term equilibrium. The negative coefficient of $\mathrm{ECT}^{+}$indicates that any price deviation in the short term which is above the long-term equilibrium, will be corrected back to the equilibrium. The value of the ECT coefficient indicates the time required for the adjustment, obtained through multiplying the coefficient value by the number of days in a year. A significant $P$-value for the ECT ${ }^{+}$coefficient indicates that the decline in one price will affect other prices. Conversely, the negative coefficient of ECT- indicates that the price deviation below the long-term balance line will not be corrected back to the equilibrium. The insignificant $P$-value indicates that the increase in one price will not affect other prices (Von Cramon-Taubadel \& Loy, 1996).

Fifth, by testing the quality of price transmission through the Wald test to prove the existence of the LOP (Grennes, 2019). Wald test is used to prove the existence of price asymmetry in the three countries. Hypothesis testing is carried out using the F-test and chisquare statistics with criteria in the short term namely $\mathrm{H}_{0}$ : If $\sum_{i=1}^{t} \beta^{-}=\sum_{i=1}^{t} \beta^{+}$, there is a symmetrical price relationship in short run, and $\mathrm{H}_{1}$ : If $\sum_{i=1}^{t} \beta^{-} \neq \sum_{i=1}^{t} \beta^{+}$, then there is an asymmetric price relationship in the short run. Whereas in the long run, $\mathrm{H}_{0}$ : If $E C T_{i t}^{-}=E C T_{i t}^{+}$, there is a symmetrical price relationship in the long run, and $\mathrm{H}_{1}$ : if $E C T_{i t}^{-} \neq E C T_{i t}^{+}$, then there is an asymmetric price relationship in the long run (Suryadi, Sahara, \& Hasbullah, 2018).

\section{TIME SERIES ANALYSIS OF FROZEN YELLOWFIN TUNA PRICES}

The ADF test was carried out to ensure

Faculty of Economics and Business,

Universitas Brawijaya that overall data are integrated in the same order. Determination of the optimum lag is based on the Akaike Information Criteria criteria. The results are demonstrated in Table 1 . The results indicate that all variables are stationary at first difference which perfectly fulfills the requirements for using the ECM model that all variables must be stationary at the same level. Therefore, further cointegration analysis is feasible.

Table 1. ADF test results

\begin{tabular}{|c|c|c|c|c|}
\hline \multirow{2}{*}{$\begin{array}{l}\text { Exporting } \\
\text { Countries }\end{array}$} & \multicolumn{2}{|c|}{ Levels } & \multicolumn{2}{|c|}{ First Differences } \\
\hline & t-stat & Prob. & t-stat & Prob. \\
\hline Indonesia & $\begin{array}{c}-\overline{-} \\
0.723\end{array}$ & 0.656 & -7.079 & $0.0000^{\star \star \star}$ \\
\hline Viet Nam & $\begin{array}{c}- \\
0.195\end{array}$ & 0.614 & -8.293 & $0.0000^{* * *}$ \\
\hline The US & $\begin{array}{c}- \\
0.071\end{array}$ & 0.657 & -10.036 & $0.0000^{* * *}$ \\
\hline
\end{tabular}

*** significant at the 0.01 significance level; Critical value at 0.01 significance level is -2.580 Source: Raw data, 2020

The cointegration test was carried out based on the Information Information Criteria (AIC). The multivariate test results are presented in Table 2. Optimal lag selection was performed based on the smallest value of Schwarz Information Criterion (SIC). The lag 2 was the optimal lag chosen according to the criterion. The results of the Johansen bivariate test indicated that there was a cointegration equation of the three prices that sheds light on the long run market integration for frozen yellowfin tuna at $5 \%$ significance level. In addition, the ADF unit residual root unit test results confirmed that the residual model is stationary at $1 \%$ significance level. These results are consistent with Jeon, Reid, \& Squires (2008) in yellowfin tuna from Bangkok and Italy markets where both have long-term price relationships as well as JiménezToribio, Guillotreau, \& Mongruel (2010) in frozen yellowfin tuna from Thailand, France, Italy, and Spain. 


\section{TESTING FOR INDONESIAN AND VIET NAM PRICE TRANSMISSION IN THE UNITED STATES TUNA MARKETS}

\section{Table 2. Bivariate Johansen test and ADF unit root test for cointegration results}

\begin{tabular}{|c|c|c|c|c|c|c|}
\hline $\begin{array}{c}\text { Variab } \\
\text { les }\end{array}$ & $\begin{array}{l}\mathrm{H}_{0} ; \\
\mathrm{Ra} \\
\mathrm{nk} \\
=\mathrm{r}\end{array}$ & $\begin{array}{l}\text { Max- } \\
\text { Eigen } \\
\text { statist } \\
\text { ics }\end{array}$ & $\begin{array}{c}\text { Critical } \\
\text { value } \\
(5 \%)\end{array}$ & $\begin{array}{c}\text { Trace } \\
\text { statistics }\end{array}$ & $\begin{array}{c}\text { Critical } \\
\text { value } \\
(5 \%)\end{array}$ & $\begin{array}{c}\text { ADF } \\
\text { unit } \\
\text { root } \\
\text { residua } \\
\text { I test }\end{array}$ \\
\hline $\begin{array}{l}\text { The } \\
\text { US }\end{array}$ & $r=0$ & $\begin{array}{c}20.21 \\
1^{* *}\end{array}$ & 11.224 & $20.452^{\star \star \star}$ & 12.320 & $\overline{-}^{-}$ \\
\hline $\begin{array}{l}\text { and } \\
\text { Indon } \\
\text { esia }\end{array}$ & $r \leq 1$ & 0.240 & 4.129 & 0.240 & 4.129 & * \\
\hline $\begin{array}{l}\text { The } \\
\text { US }\end{array}$ & $r=0$ & $\begin{array}{c}35.42 \\
1^{\star \star *}\end{array}$ & 11.224 & $35.578^{* * *}$ & 12.320 & $9.106^{\star *}$ \\
\hline $\begin{array}{l}\text { and } \\
\text { Viet } \\
\text { Nam }\end{array}$ & $r \leq 1$ & 0.157 & 4.129 & 0.157 & 4.129 & \\
\hline $\begin{array}{l}\text { Indon } \\
\text { esia } \\
\text { and }\end{array}$ & $r=0$ & $\begin{array}{c}31.99 \\
1^{\star \star *}\end{array}$ & 11.224 & $32.184^{\star \star *}$ & 12.320 & $\underset{*}{-}$ \\
\hline $\begin{array}{l}\text { Viet } \\
\text { Nam }\end{array}$ & $r \leq 1$ & 0.193 & 4.129 & 0.193 & 4.129 & \\
\hline
\end{tabular}

*** indicates a rejection of the hypothesis at 0.01 significance level

Source: Raw data, 2020

The Granger causality test in Table 3 presented a two-way relationship between Indonesia, Viet Nam, and the US. The results indicated that Indonesian frozen yellowfin tuna prices affect Viet Nam prices to the US, likewise the effect of Viet Nam prices on the Indonesia prices. Viet Nam prices also affect the US prices, and vice versa, while Indonesian prices have no relationship with the US prices. This is due to the declining value of Indonesia's exports since 2006 and the value was finally below Viet Nam since 2015 which introduced Viet $\mathrm{Nam}$ as the market leader in frozen yellowfin tuna exports to the US. Besides, Indonesia faces heavily export competition from Thailand, the Philippines and China (ITC Trade map, 2019). The majority of tuna species caught in Viet Nam are yellowfin tuna (Urch, 2016). The value of the US frozen yellowfin tuna imports from this country experienced a significant increase from US\$ 1,662 million in 2008 to US\$22,027 million in 2018. Frozen tuna account for $20 \%$ of Viet Nam's total production with the US as the largest market presently (Vietfish, 2017). There has been a massive shifting from longline to handline vessels since 2012 to reduce fishing time and fuel costs. In addition, this relates to Viet Nam yellowfin tuna status as a part of the Fishery Improvement Project for tracebility requirements since 2014 to achieve the Marine Stewardship Council Certification in 2022 (WWF, 2020). The shifting resulted Viet Nam suffered from raw

Faculty of Economics and Business, materials, especially fresh tuna. As a result, this country has intensively imported raw materials from other countries such as Japan, Taiwan, Korea, and including Indonesia. In fact, almost $60 \%$ of yellowfin tuna exported by Viet Nam presently uses imported raw materials (Phi Lai, 2016).

Table 3. Granger causality test results

\begin{tabular}{lc}
\hline Relationship & Number of lags \\
\hline Indonesia $->$ The US & 1 \\
The US -> Indonesia & 1 \\
Viet Nam -> The US & 1 \\
The US -> Viet Nam & 1 \\
Indonesia-> Viet Nam & \\
Viet Nam -> Indonesia & \\
*** significant at the 0.01 significance level; \\
** significant at the 0.05 significance level; \\
* significant at the 0.1 significance level \\
Source: Raw data, 2020
\end{tabular}

The relationship among prices is presented in Figure 1.

Figure 1. The spatial price linkages of frozen yellowfin tuna exporters and the US market

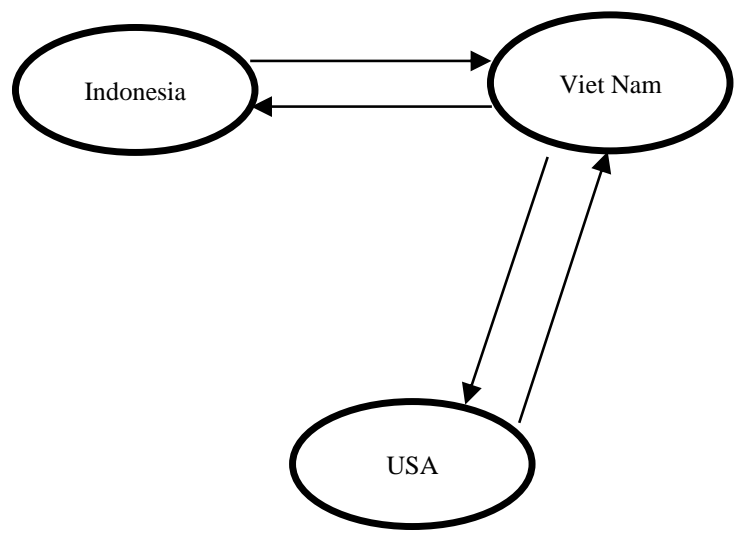

Source: Raw data, 2020

\section{THE RESULTS OF INDONESIAN AND VIET NAM ASYMMETRY PRICES}

The estimated results of short-term price transmission between Indonesia and Viet Nam are presented in Table 4 . It indicates that Indonesia prices in the previous 1 month period will affect Viet Nam prices to the US. Further long-term price transmission analysis through the negative $\mathrm{ECT}^{+}$coefficient indicates when price deviations are above the equilibrium line in the short-term, it will be corrected back to the equilibrium in the long-term. Conversely, a positive $\mathrm{ECT}^{+}$coefficient indicates that when price deviations occur below the equilibrium line, it will be corrected back to the equilibrium in the long-term. This implies when there is a decline in Indonesian prices, it is not immediately followed 
by a decline in Viet Nam prices, yet it takes approximately 3 months for Viet Nam prices to adjust downward. A significant $P$-value indicates that a fall in Indonesian prices will affect Viet Nam prices. Likewise, the price of Viet Nam in the previous 1 month period will affect the Indonesian prices to the US both due to Viet Nam increasing and decreasing prices. The positive and negative ECT coefficients indicate that in the long-term, deviations of Viet Nam prices due to alter in Indonesian prices both above and below the equilibrium line will be corrected back to the equilibrium. The insignificant P-values on both shocks indicate that both conditions will not affect Indonesian prices.

Table 4. Asymmetric Error Correction Model results for Indonesia and Viet Nam prices

\begin{tabular}{|c|c|c|c|c|}
\hline \multirow[b]{2}{*}{$\begin{array}{l}\text { Variabl } \\
\text { es }\end{array}$} & \multicolumn{2}{|c|}{$\begin{array}{c}\text { Indonesia->Viet } \\
\text { Nam }\end{array}$} & \multicolumn{2}{|c|}{$\begin{array}{l}\text { Viet Nam- } \\
\text { >Indonesia }\end{array}$} \\
\hline & $\begin{array}{l}\text { Coefficie } \\
\text { nts }\end{array}$ & $\begin{array}{c}\mathrm{P}- \\
\text { Value } \\
\mathrm{S}\end{array}$ & $\begin{array}{c}\text { Coefficie } \\
\text { nts }\end{array}$ & $\begin{array}{c}\text { P- } \\
\text { Value } \\
\mathrm{S}\end{array}$ \\
\hline$\propto_{0}$ & -0.651 & 0.169 & 0.179 & 0.585 \\
\hline$\Delta P X Y I_{t-i}^{+}$ & -0.213 & 0.109 & -0.132 & 0.146 \\
\hline$\Delta P X Y I_{t-i}^{-}$ & -0.755 & $0.000^{*}$ & 0.002 & 0.983 \\
\hline$\Delta P X Y I_{t}^{+}$ & - & - & -0.068 & 0.556 \\
\hline$\Delta P X Y I_{t}^{-}$ & - & - & -0.065 & 0.480 \\
\hline$\Delta P X Y V_{t}^{+}$ & -0.143 & 0.470 & - & - \\
\hline$\Delta P X Y V_{t}^{-}$ & -0.141 & 0.534 & - & - \\
\hline$\Delta P X Y V_{t-1}^{+}$ & 0.095 & 0.627 & -0.277 & $\underset{*}{0.036^{*}}$ \\
\hline$\Delta P X Y V_{t-1}^{-}$ & -0.157 & 0.489 & -0.423 & $\underset{* *}{0.005^{*}}$ \\
\hline$E C T_{t-1}^{+}$ & -3.835 & $0.098^{*}$ & -1.754 & 0.268 \\
\hline$E C T_{t-1}^{-}$ & 0.135 & 0.935 & 0.353 & 0.768 \\
\hline $\begin{array}{l}\text { R- } \\
\text { square } \\
\text { d }\end{array}$ & \multicolumn{2}{|c|}{0.302} & \multicolumn{2}{|c|}{0.139} \\
\hline $\begin{array}{l}\text { F- } \\
\text { statistic }\end{array}$ & \multicolumn{2}{|c|}{7.107} & \multicolumn{2}{|c|}{2.661} \\
\hline DW & \multicolumn{2}{|c|}{2.249} & \multicolumn{2}{|c|}{2.029} \\
\hline AIC & \multicolumn{2}{|c|}{4.945} & \multicolumn{2}{|c|}{4.186} \\
\hline SIC & \multicolumn{2}{|c|}{5.135} & \multicolumn{2}{|c|}{4.375} \\
\hline
\end{tabular}

*** significant at the 0.01 significance level; ** significant at the 0.05 significance level;

* significant at the 0.1 significance level Source: Raw data, 2020

\section{THE RESULTS OF VIET NAM AND THE US ASYMMETRIC PRICES}

The estimated results of short-term price transmission between Viet Nam and the US are presented in Table 5 . The US prices in the previous 1 month period will affect the US and Viet Nam prices both when prices are rising and declining. The negative $\mathrm{ECT}^{+}$coefficient indicates that when price deviations are above the equilibrium line in the short-term which implies there is a declining in the US prices, Viet Nam prices will not decrease immediately, but it will take approximately 2 months to adjust the fall. Additionally, the relationship of of Viet Nam and the US prices in the short-term indicates that Viet Nam prices in the previous 1 month significantly affect the US prices both when prices are rising and declining. Conversely, Viet Nam price deviations will not affect the US prices in the long-term.

Table 5. Asymmetric Error Correction Model results for Viet Nam and the US prices

\begin{tabular}{|c|c|c|c|c|}
\hline \multirow[b]{2}{*}{$\begin{array}{l}\text { Variabl } \\
\text { es }\end{array}$} & \multicolumn{2}{|c|}{ The US->Viet Nam } & \multicolumn{2}{|c|}{$\begin{array}{c}\text { Viet Nam->The } \\
\text { US }\end{array}$} \\
\hline & $\begin{array}{c}\text { Coefficie } \\
\text { nts }\end{array}$ & $\begin{array}{c}\text { P- } \\
\text { Value } \\
\text { s }\end{array}$ & $\begin{array}{l}\text { Coefficie } \\
\text { nts }\end{array}$ & $\begin{array}{c}P_{-} \\
\text {Value } \\
S\end{array}$ \\
\hline$\propto_{0}$ & -0.097 & 0.753 & 0.140 & 0.654 \\
\hline$\Delta P X Y U_{t-i}^{+}$ & -0.249 & $\underset{*}{0.047^{*}}$ & -0.023 & 0.850 \\
\hline$\Delta P X Y U_{t-i}^{-}$ & -0.680 & $0.000^{*}$ & 0.179 & 0.268 \\
\hline$\triangle P X Y U_{t}^{+}$ & - & - & 0.164 & 0.233 \\
\hline$\triangle P X Y U_{t}^{-}$ & - & - & 0.166 & 0.264 \\
\hline$\Delta P X Y V_{t}^{+}$ & 0.109 & 0.422 & - & - \\
\hline$\Delta P X Y V_{t}^{-}$ & 0.238 & 0.126 & - & - \\
\hline$\triangle P X Y V_{t-1}^{+}$ & 0.119 & 0.374 & -0.283 & $\underset{*}{0.033^{*}}$ \\
\hline$\Delta P X Y V_{t-1}^{-}$ & 0.105 & 0.506 & -0.432 & $0.004^{*}$ \\
\hline$E C T_{t-1}^{+}$ & -2.752 & $0.081^{*}$ & -1.176 & 0.454 \\
\hline$E C T_{t-1}^{-}$ & 0.759 & 0.527 & 0.253 & 0.831 \\
\hline $\begin{array}{l}\text { R- } \\
\text { square } \\
\text { d }\end{array}$ & \multicolumn{2}{|c|}{0.266} & \multicolumn{2}{|c|}{0.146} \\
\hline $\begin{array}{l}\text { F- } \\
\text { statistic }\end{array}$ & \multicolumn{2}{|c|}{5.935} & \multicolumn{2}{|c|}{2.812} \\
\hline DW & \multicolumn{2}{|c|}{2.201} & \multicolumn{2}{|c|}{2.072} \\
\hline AIC & \multicolumn{2}{|c|}{4.187} & \multicolumn{2}{|c|}{4.178} \\
\hline SIC & \multicolumn{2}{|c|}{4.376} & \multicolumn{2}{|c|}{4.368} \\
\hline
\end{tabular}

*** significant at the 0.01 significance level;

** significant at the 0.05 significance level;

* significant at the 0.1 significance level Source: Raw data, 2020

The results in Table 6 indicated that LOP is supported for Indonesia, Viet Nam, and the US. There is a symmetrical relationship between Indonesian and Viet Nam prices as well as Viet $\mathrm{Nam}$ and the US prices in the long-term. The relationship between Viet $\mathrm{Nam}$ and Indonesia prices also occurs in the short-term. A common reason of this incidence according to Scherer \& Ross (1990) is the existence of market forces. Since 2016, Viet Nam has surpassed Indonesia 


\section{TESTING FOR INDONESIAN AND VIET NAM PRICE TRANSMISSION IN THE UNITED STATES TUNA MARKETS}

both in terms of exported volume and value to the US. In addition, the US preference for Viet Nam tuna, which provides certification and processing facilities, has become another significant consideration. The US has set strict standards regarding the quality and sustainability of exported tuna hence Indonesian tuna is exported to Viet Nam first before it is exported to the US (Mongabay, 2019). In addition, price asymmetry only occurs in the short-term while in the long run prices adjust to equilibrium so that the price asymmetry is only temporary. Therefore, the cause of this price asymmetry is the cost adjustment (Meyer \& von Cramon-Taubadel, 2004). Adjustment or menu costs occur when countries make adjustments to prices and quantity of output due to price shocks. When the increase in costs is asymmetrical, both to the price shocks and to the quantity of output, the adjustment will be asymmetrical. In addition, another factor that can be considered for negative asymmetry is that the heavy competition with Viet Nam (Bailey \& Brorsen, 1989). The price increase could have an impact on reducing the quantity of exports to the US. This incidence will become a chance for Indonesia to increase exports in the short-term by reducing margins (Ward, 1982). However, it should be recalled that the strategy can only last for the time being. The symmetrical price relationship between Indonesia and Viet Nam implies that the price changes made by Viet Nam will be transmitted symmetrically in Indonesia. Likewise, price changes that occur in the US will be transmitted symmetrically to the two exporting countries. This indicates that the market is working competitively and Indonesia should consider improving quality and traceability in order to comply with US standards and compete with Viet Nam.

Table 6. The Law of one price test results of frozen yellowfin tuna Indonesia, Viet Nam and the US

\begin{tabular}{|c|c|c|}
\hline Relationship & $\mathrm{H}_{0}$ & LOP \\
\hline \multirow{3}{*}{$\begin{array}{l}\text { Indonesia- } \\
>\text { Viet Nam }\end{array}$} & $\begin{array}{c}\mathrm{H}_{0}: \\
\Delta P X Y V_{t}^{+}=\Delta P X Y V_{t}^{-}\end{array}$ & 3.53E-05 \\
\hline & $\begin{array}{c}\mathrm{H}_{0}: \\
\Delta P X Y V_{t-1}^{+}=\Delta P X Y V_{t-1}^{-}\end{array}$ & 0.563 \\
\hline & $\mathrm{H}_{0}: E C T_{t-1}^{+}=E C T_{t-1}^{-}$ & 1.705 \\
\hline \multirow{3}{*}{$\begin{array}{l}\text { Viet Nam- } \\
\text { >Indonesia }\end{array}$} & $\mathrm{H}_{0}: \Delta P X Y I_{t}^{+}=\Delta P X Y I_{t}^{-}$ & $13.457^{* \star *}$ \\
\hline & $\begin{array}{c}\mathrm{H}_{0}: \\
\Delta P X Y I_{t-1}^{+}=\Delta P X Y I_{t-1}^{-}\end{array}$ & 0.599 \\
\hline & $\mathrm{H}_{0}: E C T_{t-1}^{+}=E C T_{t-1}^{-}$ & 0.003 \\
\hline \multirow{3}{*}{$\begin{array}{l}\text { The US- } \\
>\text { Viet Nam }\end{array}$} & $\begin{array}{c}\mathrm{H}_{0}: \\
\Delta P X Y V_{t}^{+}=\Delta P X Y V_{t}^{-}\end{array}$ & 0.265 \\
\hline & $\begin{array}{c}\mathrm{H}_{0}: \\
\Delta P X Y V_{t-i}^{+}=\Delta P X Y V_{t-i}^{-}\end{array}$ & 0.015 \\
\hline & $\mathrm{H}_{0}: E C T_{t-1}^{+}=E C T_{t-1}^{-}$ & 0.209 \\
\hline $\begin{array}{l}\text { Viet Nam- } \\
>\text { The US }\end{array}$ & $\begin{array}{c}\mathrm{H}_{0}: \\
\Delta P X Y U_{t}^{+}=\Delta P X Y U_{t}^{-}\end{array}$ & 0.416 \\
\hline
\end{tabular}

\begin{tabular}{cc}
\hline $\mathrm{H}_{0}:$ & 0.000 \\
$\triangle P X Y U_{t-1}^{+}=\Delta P X Y U_{t-1}^{-}$ & 0.121 \\
$\mathrm{H}_{0}: E C T_{t-1}^{+}=E C T_{t-1}^{-}$ &
\end{tabular}

${ }^{\star * *}$ significance at the 0.01 significance level;

** significance at the 0.05 significance level;

* significance at the 0.1 significance level Source: Raw data, 2020

The overall analysis above reveals that both Indonesian and Viet Nam prices are cointegrated with the US prices. Viet Nam has become a market leader in frozen yellowfin tuna exports to the US so that any change in its export prices has a significant effect on Indonesian prices. The transmission of Viet Nam prices has an asymmetrical effect on Indonesian prices in the short run, albeit in the long run, the price transmission between the three countries occurs symmetrically which supports the LOP theory (Meyer \& von Cramon-Taubadel, 2004; Vinuya, 2007).

\section{CONCLUSIONS AND LIMITATIONS}

The results of this study are threefold. First, this study sheds light that the export prices of Indonesia and Viet Nam in frozen yellowfin tuna are integrated to the US prices. Second, there are two-way causality relationships between Indonesia and Viet Nam as well as Viet Nam and the US. Third, the short-term price transmission of Viet Nam has an asymmetrical effect on Indonesian prices while on the long-term, the price transmission among three countries occurs symmetrically. Indonesia's policy in increasing its market share in the US is not independent, but it is influenced by the price of Viet Nam as its main competitor. Likewise Viet Nam, where Indonesia's position as one of the suppliers of fresh tuna to Viet Nam which is important as raw material for exports. Further research is recommended to analyze the market integration and price transmission vertically between exvessel and retail prices among Indonesia, Viet Nam and the US. This is due to increasing demand for eco-friendly labeled yellowfin tuna products from the US which is followed by strong efforts from both countries to promote sustainable fisheries management, transparency and integrity supply chain and certifications.

\section{References}

Bailey, D., \& Brorsen, B. W. (1989). Price asymmetry in spatial fed cattle markets. Western Journal of Agricultural Economics, 246-252.

Ball, L., \& Mankiw, N. G. (1994). Asymmetric price adjustment and economic fluctuations. The Economic Journal, 104(423), 247-261. 
Bettendorf, L., \& Verboven, F. (2000). Incomplete transmission of coffee bean prices: evidence from the Netherlands. European Review of Agricultural Economics, 27(1), 1-16.

Borenstein, S., Cameron, A. C., \& Gilbert, R. (1997). Do gasoline prices respond asymmetrically to crude oil price changes?. The Quarterly journal of economics, 112(1), 305-339.

Buckle, R. A., \& Carlson, J. A. (2000). Inflation and asymmetric price adjustment. Review of Economics and statistics, 82(1), 157160.

Carman, H. F., \& Sexton, R. J. (2005). Supermarket fluid milk pricing practices in the Western United States. Agribusiness: An International Journal, 21(4), 509-530.

Chavas, J. P., \& Mehta, A. (2004). Price dynamics in a vertical sector: the case of butter. American Journal of Agricultural Economics, 86(4), 1078-1093.

Damania, R., \& Yang, B. Z. (1998). Price rigidity and asymmetric price adjustment in a repeated oligopoly. Journal of Institutional and Theoretical Economics (JITE)/Zeitschrift für die gesamte Staatswissenschaft, 659-679.

Dong, X., Brown, C., Waldron, S., \& Zhang, J. (2018). Asymmetric price transmission in the Chinese pork and pig market. British Food Journal.

Engle, R. F., \& Granger, C. W. (1987). Cointegration and error correction: representation, estimation, and testing. Econometrica: journal of the Econometric Society, 251-276.

Grennes, T. (2019). International financial markets and agricultural trade. CRC Press.

Huang, H., \& Leung, P. (2011). Testing for market linkages between Hawaii and Japan's tuna markets. Fisheries research, 109(2-3), 351-359.

Indonesian Pole \& Line and Handline Fisheries Association. (2019). Facts and figures of Indonesian tuna exports. https://indonesiantuna.com/2019/03/05/fact s-and-figures-of-indonesian-tuna-exports/ (2 Mei 2020).

ITC Trade Map. (2020). List of supplying markets for a product imported by United States of America.https://www.trademap.org/Country SelProductCountry TS.aspx?nvpm $=1 \% 7$ c842\%7c\%7c\%7c\%7c030342\%7c\%7c\%7c $6 \% 7 c 1 \% 7 c 1 \% 7 c 1 \% 7 c 2 \% 7 c 1 \% 7 c 2 \% 7 c 1 \%$ 7c1 (7 May 2020).

Jaffry, S., Pascoe, S., Taylor, G., \& Zabala, U. (2000). Price interactions between salmon and wild caught fish species on the Spanish market. Aquaculture Economics \& Management, 4(3-4), 157-167.

Jeon, Y., Reid, C., \& Squires, D. (2008). Is there a global market for tuna? Policy implications for tropical tuna fisheries. Ocean Development \& International Law, 39(1), 32-50.

Jiménez-Toribio, R., Guillotreau, P., \& Mongruel, R. (2010). Global integration of European tuna markets. Progress in Oceanography, 86(1-2), 166-175.

Johansen, S. (1988). Statistical analysis of cointegration vectors. Journal of economic dynamics and control, 12(2-3), 231-254.

Kementerian Kelautan dan Perikanan. (2018). Pemberlakuan SIMP oleh AS, KKP bersama kedutaan Amerika Serikat dan NOAA mengadakan workshop di Jakarta. https://kkp.go.id/dipdspkp/artikel/5531pemberlakuan-simp-oleh-as-kkp-bersamakedutaan-amerika-serikat-dan-noaamengadakan-workshop-di-jakarta (13 Mei 2020).

Kinnucan, H. W., \& Forker, O. D. (1987). Asymmetry in farm-retail price transmission for major dairy products. American journal of agricultural economics, 69(2), 285-292.

Lemmens, A., Croux, C., \& Dekimpe, M. G. (2008). Measuring and testing Granger causality over the spectrum: An application to European production expectation surveys. International Journal of Forecasting, 24(3), 414-431.

Li, F., Wang, Z., \& Liu, G. (2013). Towards an error correction model for dam monitoring data analysis based on cointegration theory. Structural Safety, 43, 12-20.

Masrizal, M., \& Naufal, A. (2019). Tingkat Degradasi dan Depresiasi Ikan Tuna Madidihang di Pesisir Utara Aceh. In Prosiding SEMDI-UNAYA (Seminar Nasional Multi Disiplin IImu UNAYA) (Vol. 3, No. 1, pp. 141-150).

Meyer, J., \& von Cramon-Taubadel, S. (2004). Asymmetric price transmission: a survey. Journal of agricultural economics, 55(3), 581-611.

Miller, D. J., \& Hayenga, M. L. (2001). Price cycles and asymmetric price transmission in the US pork market. American Journal of Agricultural Economics, 83(3), 551-562.

Mongabay. (2019). Ekspor Tuna dari Indonesia, Amerika Serikat Tekankan Perikanan Berkelanjutan.

https://www.mongabay.co.id/2019/04/17/ek spor-tuna-dari-indonesia-amerika-serikattekankan-perikanan-berkelanjutan/ (7 May 2020). 


\section{TESTING FOR INDONESIAN AND VIET NAM PRICE TRANSMISSION IN THE UNITED STATES TUNA MARKETS}

Mosley, P., \& Suleiman, A. (2007). Aid, agriculture and poverty in developing countries. Review of Development Economics, 11(1), 139-158.

Mundlak, Y., \& Larson, D. F. (1992). On the transmission of world agricultural prices. The World bank economic review, 6(3), 399-422.

Nakajima, T., Matsui, T., Sakai, Y., \& Yagi, N. (2011). Capturing changes in asymmetric price transmission: a rolling window tar estimation using bluefin tuna case study. Journal of International Fisheries, 10, 1-18.

Nielsen, M. (2005). Price formation and market integration on the European first-hand market for whitefish. Marine Resource Economics, 20(2), 185-202.

Pan, M., Sun, C. H. J., \& Squires, D. (2010). Tuna Price in Response to Changes of Market Structure and Ecosystem Conditions-Price Linkage Between Hawaii and Japanese Tuna Sashimi Markets.

Peltzman, S. (2000). Prices rise faster than they fall. Journal of political economy, 108(3), 466-502.

Richards, T. J., \& Patterson, P. M. (2003). Competition in fresh produce markets: an empirical analysis of marketing channel performance (No. 2239-20192814).

Seafish. (2019). Export guide: Viet Nam. Market reserah report. https://www.seafish.org/media/Vietnam Ex port Guide.pdf (2 Mei 2020).

Songsiengchai, P., Sidique, S. F., Djama, M., \& Azman-Saini, W. N. W. (2018). Asymmetric adjustments in the Thai palm oil market. Kasetsart Journal of Social Sciences.

Statista. (2019). U.S. imports of tuna from 2009 to 2018, by species (in metric tons). https://www.statista.com/statistics/197982/ united-states-imports-of-tuna-by-species/ (2 May 2020).

Suryadi, A., Sahara, S., \& Hasbullah, R. (2018). Integrasi dan Asimetri Harga Karet TSR20 Indonesia dengan Harga TSR20 Dunia. Jurnal Aplikasi Bisnis dan Manajemen (JABM), 4(3), 354-354.
Turner, P. (2009). Testing for cointegration using the Johansen approach: are we using the correct critical values?. Journal of Applied Econometrics, 24(5), 825-831.

Urch, M. (2016). Vietnam's tuna exports rise, with Israel a potential new market. https://www.seafoodsource.com/news/sup ply-trade/vietnam-s-tuna-exports-rise-withisrael-a-potential-new-market (7 May 2020).

VietFish. (2017). Tuna export increases $21 \%$ in the first six months. http://vietfishmagazine.com/markets/tunaexport-increases-21-first-six-months.html (7 May 2020).

Phi Lai, T. (2016). Fit for FIP (F4F) traceability for Vietnam yellowfin tuna: Summary of supply chains, current practices, and proposed F4F traceability system. Vietnam Fisheries Improvement Project.

Ravallion, M. (1986). Testing market integration. American Journal of Agricultural Economics, 68(1), 102-109.

Van Campenhout, B. (2007). Modelling trends in food market integration: Method and an application to Tanzanian maize markets. Food policy, 32(1), 112-127.

Vinuya, F. D. (2007). Testing for market integration and the law of one price in world shrimp markets. Aquaculture Economics \& Management, 11(3), 243-265.

Von Cramon-Taubadel, S., \& Loy, J. P. (1996). Price asymmetry in the international wheat market: Comment. Canadian Journal of Agricultural Economics/Revue canadienne d'agroeconomie, 44(3), 311-317.

Ward, R. W. (1982). Asymmetry in retail, wholesale, and shipping point pricing for fresh vegetables. American journal of agricultural economics, 64(2), 205-212.

WWF. (2020). Fisheries Improvement Project. https://vietnam.panda.org/en/our work/oce ans/fisheries/ (7 May 2020).

Yusuf, R., Arthatiani, F. Y., \& Maharani, H. (2018). Kinerja ekspor tuna indonesia: suatu pendekatan analisis bayesian. Jurnal Kebijakan Sosial Ekonomi Kelautan dan Perikanan, 7(1), 39-50. 